\title{
Matching patterns with processes: predicting the effect of size and mobility on the spatial distributions of the bivalves Macomona liliana and Austrovenus stutchburyi
}

\author{
J. E. Hewitt*, S. F. Thrush, V. J. Cummings, R. D. Pridmore \\ National Institute of Water and Atmospheric Research, PO Box 11-115, Hamilton, New Zealand
}

\begin{abstract}
Descriptions of patterns of community or population variation in space can provide a stepping stone to inferring the relevant processes affecting spatial patterns. However, matching patterns to particular processes has proven difficult. In this study we make a priori predictions about the form and intensity of spatial patterns in abundance of the infaunal bivalves Macomona liliana and Austrovenus stutchburyi based on size, feeding mode and mobility. These predictions are tested by describing the spatial patterns found for a range of scales $(5$ to $33 \mathrm{~cm}$ and $33 \mathrm{~cm}$ to $6 \mathrm{~m}$ ). In order to incorporate environmental variation, patterns were studied at 2 sites of different sediment grain size and hydrodynamic regime. Most of the spatial patterns found were the same in intensity and patch size at both sites, suggesting that biological rather than environmental processes were important. In particular, patch size appeared to be a function of mobility for all but $M$. liliana juveniles. Over the scales investigated in this study, individual mobility and inter-individual interactions appeared important processes influencing the observed spatial patterns of both juveniles and adults of these 2 functionally different species. This has important implications, as the ability to predict the relative importance of different processes through an understanding of an organism's natural history allows a much better appreciation of the effects of generalising results from small-scale studies
\end{abstract}

KEY WORDS: Bivalve $\cdot$ Mollusc S Spatıal patterns Mobility Body size

\section{INTRODUCTION}

Ecology is essentially the study of the heterogeneity of communities, populations or individuals and of the processes that influence them, in space and time. Heterogeneity results from a complex interaction of abiotic and biotic processes (Whitaker \& Levin 1977, Livingston 1987, Root 1988, Caswell \& Cohen 1991). Recognition that processes can vary in their importance over different spatial and temporal scales has led to the realisation that descriptions of spatial patterns of community or population heterogeneity can provide a stepping stone to inferring relevant processes (Maurer 1985, Steele 1985, Wiens 1986). However, matching

·E-mail: hewitt@eco.cn,nz observed patterns to particular processes has proven difficult.

Studying the abundance of organisms over a variety of scales usually reveals mosaics of patches within patches. Thus, understanding the hierarchical nature of patchiness and the scale over which processes and responses operate may be necessary in order to link spatial patterns to the processes which structure them (Kotliar \& Wiens 1990, Milne 1991a, O'Neill et al. 1991) Ecological cause and effect studies hoping to elucidate complex and often indirect relationships need to be well focused and sensitive to responses that change with scale. One contribution that will enable us to better focus such studies is to develop techniques enabling us to isolate appropriate or inappropriate processes contributing to patterns on particular scales 
With studies at the correct spatial scale we should be able, if not to infer the relevant processes from the pattern, at least to predict the expected pattern from known processes and thus determine whether the processes are eliciting the expected response. Many ecologists have suggested that the scale at which organisms interact with the environment is usually a function of body size, feeding area and mode and mobility (e.g. Levinton 1972. Addicot et al. 1987, Williamson \& Lawton 1991, Milne 1992). With knowledge of body size, types of feeding and mobility, it should be possible to design studies to investigate the relative importance of these processes in determining spatial patterns of abundance

In this study we make predictions based on basic knowledge of the life histories of 2 bivalves (Macomona liliana and Austrovenus stutchburyi) and their environment, as to what type/scale of spatial patterns we would expert to find in their abundances. Juveniles and adults were treated separately as many infaunal species exploit different resources and change their degree of mobility between life stages and may, therefore, exhibit different spatial patterns over their life cycle. The range of scales investigated ( 5 to $33 \mathrm{~cm}$ and $33 \mathrm{~cm}$ to $6 \mathrm{~m}$ ) was considered to encompass individual interactions and crawling movement. In order to incorporate environmental variation, 2 sites of different sediment grain size and hydrodynamic regime were studied. We describe the spatial patterns found for the different size classes of the 2 species and match these to our predictions. We then attempt to utilise the type and scale of patterns found to increase our knowledge of the ecology of these 2 species.

\section{METHODS}

Study species. The tellinid bivalve, Macomona liliana, is a deposit feeder which grows up to $60 \mathrm{~mm}$ in length (Powell 1979). Adult $M$ liliana live within the sediment to depths of $1.0 \mathrm{~cm}$ and feed at the surface by means of a long inhalant siphon. Movement of adults is limited, with previous work (Thrush et al. 1994) suggesting that movement out of patches greater than $1 \mathrm{~m}$ radius is not likely to occur even over a 5 mo period. Incividual movement rates of maximally $10 \mathrm{~cm}$ over 1 tidal cycle and 20 to $30 \mathrm{~cm}$ over $3 \mathrm{wk}$ have also been observed (authors' unpubl. obs). Juveniles $(<3 \mathrm{~mm}$ longest shell dimension), however, inhabit the top $2 \mathrm{~cm}$ of the sediment only and undergo post-settlement dispersal both associated with sediment bedload and by drifting in the water column (Pridmore et al. 1991, Cummings et al. 1993, 1995, Commito et al. 1995).

The venerid bivalve Austrovenus stutchburyi is a suspension feeder with very short siphons which grows up to $60 \mathrm{~mm}$ in length (Powell 1979). Both the adult and juvenile life stages live in near-surface sediment, and tracks left by the adults crawling across the sediment surface are readily visible Movement by adults of this species is much greater than that of the adult Macomona liliana, with individuals easily moving $30 \mathrm{~cm}$ over a single tide (authors unpubl. obs.). Juveniles are frequently found moving with the bedload (Commito et al. 1995) but are less frequently found in the water column than are juvenile $M$. liliana (Pridmore et al. 1991, Cummings et al. 1995).

The differences in feeding and mobility exhibited by these 2 species in their adult and juvenile life stages make these species good candidates for assessing the influence of body size and basic natural history traits on spatial distributions of abundance.

Study sites. The study was conducted on 2 mid-tide flats at the mouth of a small creek (Pukaki Creek) on the eastern side of the large $\left(340 \mathrm{~km}^{2}\right)$ Manukau Harbour ( $37^{\circ} 02^{\prime} \mathrm{S}, 174^{\circ} 41^{\prime} \mathrm{E}$ ), New Zealand. The extensive intertidal flats at the mouth of the creek face directly into the prevailing southwesterly winds with a fetch of $15 \mathrm{~km}$ and protect the creek itself. One site (sandy site) was located on an exposed sandflat just outside the mouth of the creek while the other (muddy site), was located approximately $1 \mathrm{~km}$ away on a sheltered mudflat within the creek. The 2 sites span the sediment grain size over which Macomona liliana and Austrovenus stutchburyi usually co-occur. The sandy site was composed predominantly of well-compacted fine sand with less than $3 \%$ silt/clay. The muddy site was composed of a surface $(0$ to $5 \mathrm{~cm})$ layer of uncompacted very fine sand, with $23 \%$ silt/clay, over a layer of sand, shell hash and clay.

The major large predators at both the sites are a variety of migrant and resident shorebirds and eagle rays Myliobatus tenuicaudatus, although the rays feed more often in the sandy site area (authors' unpubl. obs). These rays create large crater-like holes (50 to $100 \mathrm{~cm}$ in diameter) when feeding. However, by the time the holes have been infilled to the same degree of compaction as the surrounding sediment (a maximum of $12 \mathrm{~d}$ ), the communities within the disturbed areas have returned to normal densities (Thrush et al. 1991). Neither of the sites showed signs of being targeted by rays in the $12 \mathrm{~d}$ before sampling took place. There was a general lack of small epibenthic predators at both sites, although crabs Halicarcinus whitei and Helice crassa were more commonly observed at the muddy site. Common macrofauna at each site were similar, although their densities and relative dominance differed (Table 1).

Study design. Previous work on the 2 species (Thrush et al. 1989) indicated spatial variability on scales of $<5 \mathrm{~m}$ within larger patches of 10 to $25 \mathrm{~m}$ 
Table 1 . Common species at the 2 sites given in order of abundance. Mean number of individuals \pm SE per $10 \mathrm{~cm}$ core are given. Taxonomic affiliation: $P$, polychaetes; $B$, bivalves

\begin{tabular}{|lc|}
\hline Species & no. core $^{-1} \pm \mathrm{SE}$ \\
\hline Sandy site & \\
Aonides oxycephala (P) & $41 \pm 1.1$ \\
Austrovenus stutchburyi (B) & $14 \pm 0.4$ \\
Macomona liliana (B) & $10 \pm 0.2$ \\
Nucula hartvigiana (B) & $4 \pm 0.2$ \\
Nemerteans & $2 \pm 0.1$ \\
Paphies australis (B) & $2 \pm 0.1$ \\
Muddy site & \\
Aonides oxycephala & $26 \pm 0.7$ \\
Nucula hartvigiana & $9 \pm 0.3$ \\
Austrovenus stutchburyi & $6 \pm 0.2$ \\
Sphaerosyllis semiverricosa (P) & $3 \pm 0.4$ \\
Macomona liliana & $3 \pm 0.1$ \\
Aquilaspio aucklandica (P) & $2 \pm 0.1$ \\
\hline
\end{tabular}

radius. In this study we set the upper scale of our sampling design to be $6 \mathrm{~m}$ to allow good determination on the scale of $<5 \mathrm{~m}$, as we anticipated that it would be at these scales that individual crawling movement and inter-individual interactions were most likely to be influential. Two sizes of corer were used. The smaller corer ( $5 \mathrm{~cm}$ diameter, $12 \mathrm{~cm}$ depth) was slightly larger than the size of the adult Macomona liliana and Austrovenus stutchburyi ( 30 to $40 \mathrm{~mm}$ longest shell axis) found at these sites. This corer was used in a contiguous design to evaluate inter-individual distances. The larger corer (10 cm diameter, $12 \mathrm{~cm}$ depth) was selected to give an average of more than 2 adult individuals of each species per core and was used to evaluate larger-scale patterns.

At each site, a $5 \times 5 \mathrm{~m}$ area was marked out into a $33 \times 33 \mathrm{~cm}$ grid. Cores $(10 \mathrm{~cm}$ diameter) were taken from each grid point. An extra 5 cores were taken at the $(0 \mathrm{~m}, 6 \mathrm{~m}),(3 \mathrm{~m}, 6 \mathrm{~m}),(6 \mathrm{~m}, 6 \mathrm{~m}),(6 \mathrm{~m}, 3 \mathrm{~m})$ and $(6 \mathrm{~m}, 0 \mathrm{~m}$ ) coordinates, extending the $5 \times 5 \mathrm{~m}$ area into a $6 \times 6 \mathrm{~m}$ area. Nine $25 \times 30 \mathrm{~cm}$ areas were placed within the grid at 1 to $2 \mathrm{~m}$ intervals. Within each of these areas, thirty $5 \mathrm{~cm}$ diameter contiguous cores were taken in a patch $25 \times 30 \mathrm{~cm}$. The sandy site was sampled on 21 January 1991; the muddy site was sampled on 13 February 1991. Sampling the 2 sites at different times serves to strengthen the inferences obtainable from finding similar spatial patterns at the 2 sites.

After collection, all samples were sieved $(500 \mu \mathrm{m}$ mesh) and the residue fixed in 5\% formalin and $0.1 \%$ Rose Bengal in seawater. For the larger cores, all macrofauna was sorted, identified, counted and preserved in $70 \%$ alcohol. For the smaller cores, only numbers of Austrovenus stutchburyi and Macomona
Liliana were documented. The lengths of individual $A$. stutchburyi and $M$. liliana from both core sizes were measured (longest shell axis) to the nearest $0.1 \mathrm{~mm}$ using electronic callipers for individuals larger than $10 \mathrm{~cm}$, and a dissecting microscope, camera lucida and digitiser for smaller specimens

Definitions. Spatial patterns have 2 aspects: intensity and form (Pielou 1977). Intensity is assessed by methods which sort distributions of density estimates into aggregated, uniform or not significantly different from random. The form of spatial pattern is determined by methods which utilize information contained in the spatial location of individuals. In terms of study design, there are 3 separate important components of scale: grain, the area of the sampler unit; lag, the intersample distance; and extent, the total area from which samples are collected (see Legendre \& Legendre 1983, Isaaks \& Srivastava 1989, Wiens 1989)

Data analysis. Initially both bivalve species were divided into 4 size classes (i.e. $\leq 2.5,2.5-5.0,5.0-$ 10.0 and $>10 \mathrm{~mm}$ ) and frequency size distributions were plotted for each species at each site. However, all subsequent analyses were confined to the number of individuals in 2 size classes, i.e. $>10$ and $\leq 2.5 \mathrm{~mm}$. These 2 size classes made up more than $70 \%$ of the populations at both sites and individuals of Macomona liliana and Austrovenus stutchburyi smaller than $2.5 \mathrm{~mm}$ commonly move in the water column and with bedload (Pridmore et al. 1991, Cummings et al. 1993, Commito et al. 1995). Differences in the number of individuals of different sizes between the 2 sites were tested for significance using t-tests, after using the Kolmogorov-Smirnov test for normality.

The form of spatial pattern was investigated using spatial autocorrelograms of Moran's I and Geary's c (SAAP; Wartenberg 1989) with lags of $5 \mathrm{~cm}, 10 \mathrm{~cm}$ and $1 \mathrm{~m}$ for the small contiguous cores, and $33 \mathrm{~cm}, 67 \mathrm{~cm}$ and $1 \mathrm{~m}$ for the larger cores. Using a lag of $1 \mathrm{~m}$ (i.e. samples lying within 0 to $1 \mathrm{~m}$ of each other, 1 to $2 \mathrm{~m}$ of each other etc.) for each core size allowed us to check that the same patterns were apparent for both the $5 \mathrm{~cm}$ and the $10 \mathrm{~cm}$ diameter core sampling strategies. Similarly the intermediate lags of 10 and $67 \mathrm{~cm}$ provided corroboration of the results from the 5 and $33 \mathrm{~cm}$ lags respectively. For the spatial autocorrelograms the null hypothesis of $I=0$ for each distance class was tested at the $5 \%$ probability level $(\alpha)$ using the normal approximation, with corrections to the upper and lower percentage tails being applied as necessary (see Jumars et al. 1977, Sokal \& Oden 1978, Cliff \& Ord 1981). Before examining each significant value in a correlogram, a 'global' test was performed to check whether the correlogram contained at least 1 value which was significant at the $\alpha^{\prime}=\alpha / v$ significant level, where $v$ is the number of tests performed (Oden 1984). Autocorrelo- 
Table 2. Summary of the sizes of the grains and extents used in the correlation analyses, together with the resultant degrees of freedom

\begin{tabular}{|cccc|}
\hline Grain (cm) & & $\begin{array}{c}\text { Extent } \\
6 \times 6 \mathrm{~m}\end{array}$ & $1 \mathrm{~km}$ \\
\hline 5 & $25 \times 30 \mathrm{~cm}$ & 269 & 539 \\
10 & 29 & 53 & 107 \\
15 & - & 17 & 35 \\
20 & - & 8 & 17 \\
25 & - & 8 & 17 \\
\hline
\end{tabular}

grams were interpreted to identify various forms of mean spatial structure using the guidelines presented by Sokal (1979) and Legendre \& Fortin (1989).

Autocorrelograms provide information on average spatial patterns, thus similar autocorrelograms do not necessarily indjcate similarity in spatial location (Sokal \& Oden 1978). Therefore, correlations between sizeclasses and/or species were investigated using Pearson's $r$, adjusted for spatial correlation by the method given in Griffith (1987), with the probability level adjusted for the number of correlations run. In order to study interactions between mobility, grain and significance of the correlations (Schneider \& Piatt 1986), the small contiguous cores were pooled to provide quadrats of $10,15,20$ and $25 \mathrm{~cm}^{2}$. The extent of the study area can also have an effect on correlation coef. ficients, usually as a result of the study area having either too little or too much variation in the correlates. Three possible extents were used in this study: the $25 \times 30 \mathrm{~cm}$ contiguous grids, the $6 \times 6 \mathrm{~m}$ grids and the 2 study sites separated by approximately $1 \mathrm{~km}$ (see Table 2).

The intensity of spatial patterns was investigated using Morisita's standardised index of dispersion (Krebs 1989). Distribution patterns were then identified as aggregated, random or uniform. Uniform distributions are rare in nature (Pielou 1977) and are generally attributable to environmental features or negative interaction between individuals (Holme 1950, Connell 1963) such as territoriality or competition (Reise 1979. Levin 1981). The grain used in these analyses (see Table 2) can again significantly influence results. In particular, the grain at which uniform distributions are found provides some indication of the spatial range of inter-individual interactions.

\section{PREDICTIONS}

The a priori predictions made in this study deal with 4 main topics: similarity in spatial patterns between sites, within-site patch structure over different spatial scales, intensity of pattern, and presence of correlations between different size classes and species. In each case we made predictions about general categories of patch size, i.e. small $(\leq 33 \mathrm{~cm}$ diameter), medium (50 cm to $1 \mathrm{~m}$ diameter) and large scale (several meters diameter).

Similarity between sites. At the scales of the study, individual characteristics (e.g. mobility, interactions) should strongly influence the spatial patterns found, even though small-scale resource heterogeneity, hydrodynamic patterns and predator pressures were most likely to be different. Therefore, we predicted that:

Similar spatial patterns would be found at both sites, for each size class of each species

Patch structure. For adults of both species, we predicted that this would be a function of mobility, i.e.

The least mobile individuals (Macomona liliana adults) would exhibit small- to medium-scale patches

The moderately mobile (Austrovenus stutchburyi adults) would exhibit medium- to largescale patches

Juveniles of both species were harder to make predictions about. Previous work has suggested that more mobile species will interact with a larger landscape mosaic than sedentary species (Milne 1991b, 1992), which may result in highly mobile populations being less sensitive to local spatial conditions (Kotliar \& Wiens 1990, Milne 1991a). Thus, we might have predicted that the highly mobile Macomona liliana juveniles would not exhibit patterns of abundance at the scale of this study. However, we knew from previous experiments (Thrush et al. 1992, Cummings et al. in press) that $M$. liliana juveniles exhibit habitat selectivity and/or differential survival over small spatial scales. Thrush et al. $(1992,1994)$ suggested that juveniles of this species can respond to patches of adults on a scale of $20 \mathrm{~cm}$ to $2 \mathrm{~m}$ diameter. Therefore, our prediction was:

The highly mobile juvenile $M$. liliana would exhibit patches in density of a similar size as those of the conspecific adults

For terrestrial systems many ecologists have suggested that the scale at which organisms interact with the environment is usually a function of body size (Brown 1981, Peters 1983, Swihart et al. 1988). In marine environments this will obviously be complicated by the fluidity of the habitat affecting the mobility of organisms with a higher potential for smaller organisms to be transported over larger distances with water or sediment movement. However, as juveniles have only occasionally been found in the water column, and movement with sediment is likely to be on a 
smaller scale than movement with water, we decided to test the prediction that:

For Austrovenus stutchburyi, patch size would be a function of body size with smaller patches detected for the juveniles than for the adults

Intensity of pattern. Differences in the intensity of spatial pattern should result from functional differences in the 2 species. Suspension feeders are not expected to exhibit uniform distribution patterns; rather, aggregated or random patterns are found (Levinton 1972, Gage \& Geekie 1973). However, over small spatial scales, deposit feeders can be uniformly distributed due to competition and the establishment of feeding territories (Holme 1950, Levinton 1972). Therefore we predicted that:

The deposit-feeding Macomona liliana would exhibit uniform distributions at small scales

The suspension-feeding Austrovenus stutchburyi would exhibit aggregated or random behaviour

Correlations. Past experiments have suggested that Macomona liliana adults can facilitate or inhibit recruitment of juvenile conspecifics (Thrush et al. 1992, 1994). However, no evidence has been found of interactions between adult and juvenile Austrovenus stutchburyi. Therefore, we predicted that:

For Macomona liliana there would be a conspecific adult-juvenile interaction; we could not predict whether this would be positive or negative

Table 3. Macomona liliana and Austrovenus stutchburyi. Percentage frequency distributions of size classes found at the 2 sites with the 2 sizes of corers

\begin{tabular}{|c|c|c|c|c|}
\hline Site & Species & $\begin{array}{l}\text { Size class } \\
(\mathrm{mm})\end{array}$ & $\begin{array}{l}\text { Large } \\
\text { corers }\end{array}$ & $\begin{array}{l}\text { Small } \\
\text { corers }\end{array}$ \\
\hline \multirow[t]{2}{*}{ Sandy } & M. liliana & $\begin{aligned} & \leq 2.5 \\
& -5.0 \\
-10.0 & \\
> & 10\end{aligned}$ & $\begin{array}{l}32 \\
17 \\
14 \\
37\end{array}$ & $\begin{array}{l}30 \\
14 \\
14 \\
42\end{array}$ \\
\hline & A. stutchburyi & $\begin{array}{r}\leq 2.5 \\
-5.0 \\
-10.0 \\
>10\end{array}$ & $\begin{array}{r}36 \\
18 \\
4 \\
42\end{array}$ & $\begin{array}{r}37 \\
18 \\
4 \\
41\end{array}$ \\
\hline \multirow[t]{2}{*}{ Muddy } & M. liliana & $\begin{array}{l}\leq 2.5 \\
-5.0 \\
-10.0 \\
>10\end{array}$ & $\begin{array}{l}10 \\
14 \\
10 \\
66\end{array}$ & $\begin{array}{r}9 \\
10 \\
10 \\
72\end{array}$ \\
\hline & A. stutchburyi & $\begin{array}{l}\leq 2.5 \\
-50 \\
-10.0 \\
>10\end{array}$ & $\begin{array}{r}4 \\
3 \\
2 \\
91\end{array}$ & $\begin{array}{r}6 \\
3 \\
2 \\
89\end{array}$ \\
\hline
\end{tabular}

For Austrovenus stutchburyi there would be no conspecific adult-juvenile interaction

(9)

\section{RESULTS}

The percentage frequencies of Macomona liliana and Austrovenus stutchburyi found in each size class obtained by the different sized corers were similar (Table 3). Density estimates of adult A. stutchburyi were similar at both sites (Fig. 1). However, significantly larger numbers of adult $M$. liliana and juveniles of both species were found at the sandy site than at the muddy site (Table 4).
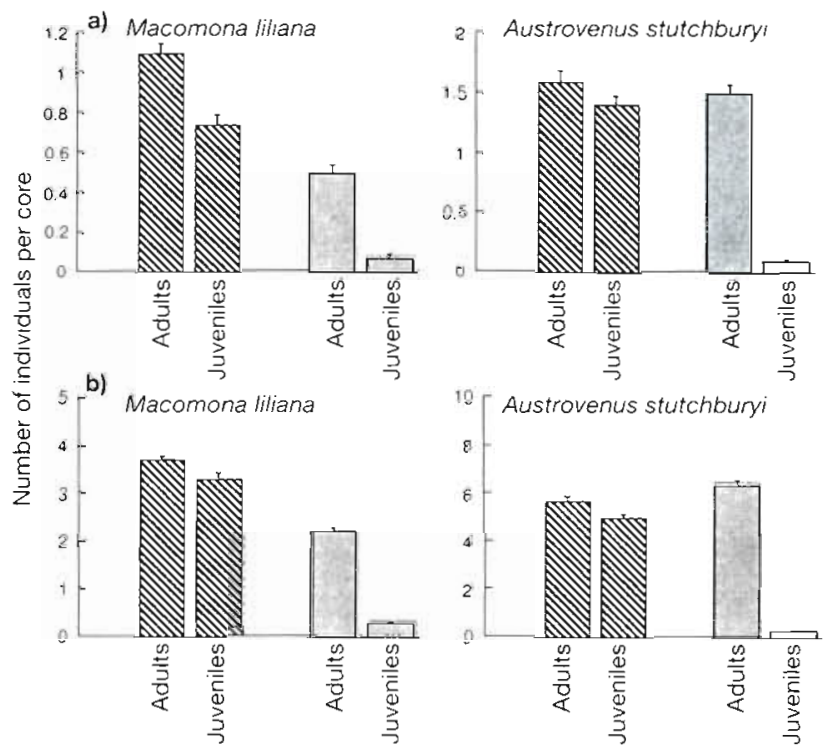

Fig. 1. Macomona Liliana and Austrovenus stutchburyi. Mean abundance and standard error of the numbers of juvenile $(\leq 2.5 \mathrm{~mm})$ and adult $(>10 \mathrm{~mm})$ bivalves found in the (a) small and (b) large cores at the sandy (striped bars) and muddy (shaded bars) sites

Table 4. Macomona Lliana and Austrovenus stutchburyl Comparisons of the numbers of juvenile and adult bivalves found at the sandy site with numbers found at the muddy site. An $F_{\max }$ test for equality of variances determined whether the $t$-test for equal or unequal variances was used

\begin{tabular}{|c|c|c|c|c|c|c|}
\hline & \multicolumn{3}{|c|}{ Large corers } & \multicolumn{3}{|c|}{ Small corers } \\
\hline & t-value & $d f$ & $\mathrm{p}$ & t-value & $\mathrm{df}$ & $\mathrm{p}$ \\
\hline \multicolumn{7}{|l|}{ M. liliana } \\
\hline Juveniles & -21.987 & 512 & $<0.0001$ & -12.211 & 316 & 0.0001 \\
\hline Adults & -13.087 & 512 & $<0.0001$ & -10.018 & 522 & 0.0001 \\
\hline \multicolumn{7}{|c|}{ A stutchburyi } \\
\hline Juveniles & -27.119 & 511 & $<0.0001$ & -16.484 & 313 & 0.0001 \\
\hline Adults & 1.648 & 512 & 0.0946 & -0.829 & 538 & 0.4073 \\
\hline
\end{tabular}



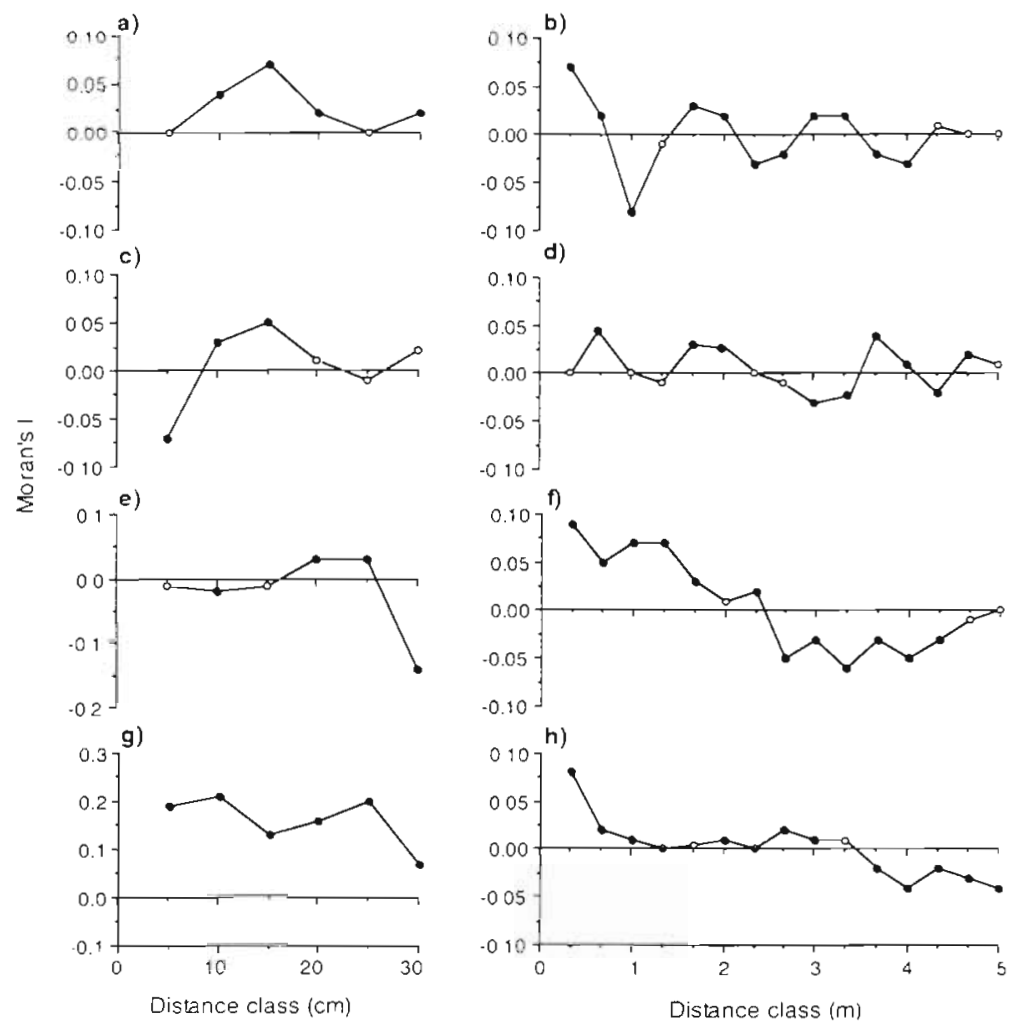

Fig 2. Moran's I correlograms for Macomona liliana ( $a, b)$ juveniles and $(c, d)$ adults and Austrovenus stutchburyi (e, f) juveniles and $(\mathrm{g}, \mathrm{h})$ adults at the sandy site. Correlograms on the left and right of the figure were obtained using data from the small and large cores respectively. ( Values of Moran's I significant at the 5\% probability level

Only the Moran's I correlograms for lags of $5 \mathrm{~cm}$ for the small contiguous cores and lags of $33 \mathrm{~cm}$ for the larger cores are presented, as using the other tech-

Table 5. Macomona liliana and Austrovenus stutchburyi. Summary of spatial patterns (patch sizes) obtained for juvenile and adult bivalves at the 2 sites

\begin{tabular}{|ccc|}
\hline & Sandy site & Muddy site \\
\hline $\begin{array}{l}\text { M. liliana } \\
\text { Juveniles }\end{array}$ & $<5 \mathrm{~cm}(?)$, & \\
& $25 \mathrm{~cm}$, & $<5 \mathrm{~cm}$, \\
& $67 \mathrm{~cm}-1 \mathrm{~m}$, & $67 \mathrm{~cm}-1 \mathrm{~m}$ \\
Adults & $<5 \mathrm{~cm}$, & \\
& $20 \mathrm{~cm}$, & $15-20 \mathrm{~cm}$, \\
& $67 \mathrm{~cm}-1 \mathrm{~m}$, & $67 \mathrm{~cm}-1 \mathrm{~m}$ \\
A. stutchburyl & & $<5 \mathrm{~cm}$, \\
Juveniles & $25-30 \mathrm{~cm}$, & $25 \mathrm{~cm}$, \\
& $2.0-2.7 \mathrm{~m}$ & $2.0-3.0 \mathrm{~m}$ \\
& & $1.3-1.7 \mathrm{~m}$, \\
Adults & $1.3 \mathrm{~m}$, & $3.0-3.3 \mathrm{~m}$ \\
& $3.0-3.7 \mathrm{~m}$ & \\
\hline
\end{tabular}

niques and/or lags demonstrated similar results. Figs. 2 \& 3 show Moran's I correlograms for the different combinations of size-class/species/size of corer at the sandy and the muddy sites respectively. Generally, species or size classes with correlograms for the large cores demonstrating structures of $<33 \mathrm{~cm}$ had correlograms for the small cores demonstrating patterns $<33 \mathrm{~cm}$. It should be noted that it is actually not possible to distinguish between patches with a diameter greater than half the extent of the sampled area and larger-scale gradients.

At the sandy site, Macomona liliana juveniles exhibited 3 scales of patchiness: probable small-scale heterogeneity (i.e. less than our smallest intersample distance of $5 \mathrm{~cm}$ ) within patches of $25 \mathrm{~cm}$ diameter, with larger patches of $67 \mathrm{~cm}$ to $1 \mathrm{~m}$ diameter being apparent at further lags (Fig. 2a, b). Adult $M$. liliana also exhibited 3 scales of patchiness: smallscale heterogeneity within patches of $20 \mathrm{~cm}$ diameter within larger patches of $67 \mathrm{~cm}$ to $1 \mathrm{~m}$ diameter (Fig. 2c, d). Austrovenus stutchburyi juveniles exhibited patches of 25 to $30 \mathrm{~cm}$ diameter within much larger patches of 2.0 to $2.7 \mathrm{~m}$ diameter (Fig. 2e, f). A. stutchburyi adults exhibited no small-scale patterns (Fig. 2g). The clearest spatial structure apparent from Fig. $2 \mathrm{~h}$ was a $1.3 \mathrm{~m}$ diameter patch within a larger (3.0 to $3.7 \mathrm{~m}$ diameter) patch.

At the muddy site, patchiness also occurred on more than 1 scale. Juvenile Macomona liliana again exhibited small-scale heterogeneity (Fig 3a); within medium-scale patches of $67 \mathrm{~cm}$ to $1 \mathrm{~m}$ diameter (Fig. 3b). Austrovenus stutchburyi juveniles demonstrated small-scale heterogeneity (Fig. 3e) and $30 \mathrm{~cm}$ diameter patches within larger patches. The structure of the larger patches is unclear from Fig. $3 \mathrm{f}$, with indications of structure occurring at $33 \mathrm{~cm}, 1.3 \mathrm{~m}$ and $3.0 \mathrm{~m}$. Analysis with a $1 \mathrm{~m}$ lag together with Geary's c correlograms at all lags and the $5 \mathrm{~cm}$ core analysis suggest a structure of patches of $25 \mathrm{~cm}$ diameter within larger patches of 2.0 to $3 \mathrm{~m}$ (Fig. 4). M. liliana adults exhibited small patches of 15 to $20 \mathrm{~cm}$ diameter within larger $67 \mathrm{~cm}$ to $1 \mathrm{~m}$ diameter patches (Fig. 3c, d). Again, the spatial structure of the $A$. stutchburyi adults was relatively large (Fig. $3 \mathrm{~g}, \mathrm{~h}$ ). The clearest structure is that of a 1.3 to $1.7 \mathrm{~m}$ diameter patch, although there are further indications of structure at 3.0 to $3.3 \mathrm{~m}$.

Summarising across the 2 sites, certain patterns become apparent (Table 5). Adult Macomona liliana 
and Austrovenus stutchburyi and juvenile $A$. stutchburyi exhibit similar patterns at both sites. However, $M$. liliana juveniles demonstrate different smallscale spatial structure, with the muddy site exhibiting only small-scale heterogeneity and no evidence of the 20 to $30 \mathrm{~cm}$ diameter patches found at the sandy site.

No significant correlations were obtained for the separate sites. However, when the range of abundances being investigated was increased by utilizing data from both sites, the strength and significance of the relationships increased (Table 6). Relationships between adult Macomona liliana and juveniles of both species were found at all quadrat sizes with the strongest relationships at the larger quadrat sizes. However, there were no significant correlations between the adults of the 2 species.

Results of the analyses for intensity of spatial patterns are given in Table 7 . Adult Macomona liliana at both sites were randomly distributed at all except the $10 \mathrm{~cm}$ scale where they were evenly dispersed. Adult Austrovenus stutchburyi, on the other hand, were aggregated at all scales at both sites. Juveniles of neither species showed any consistent patterns between sites.
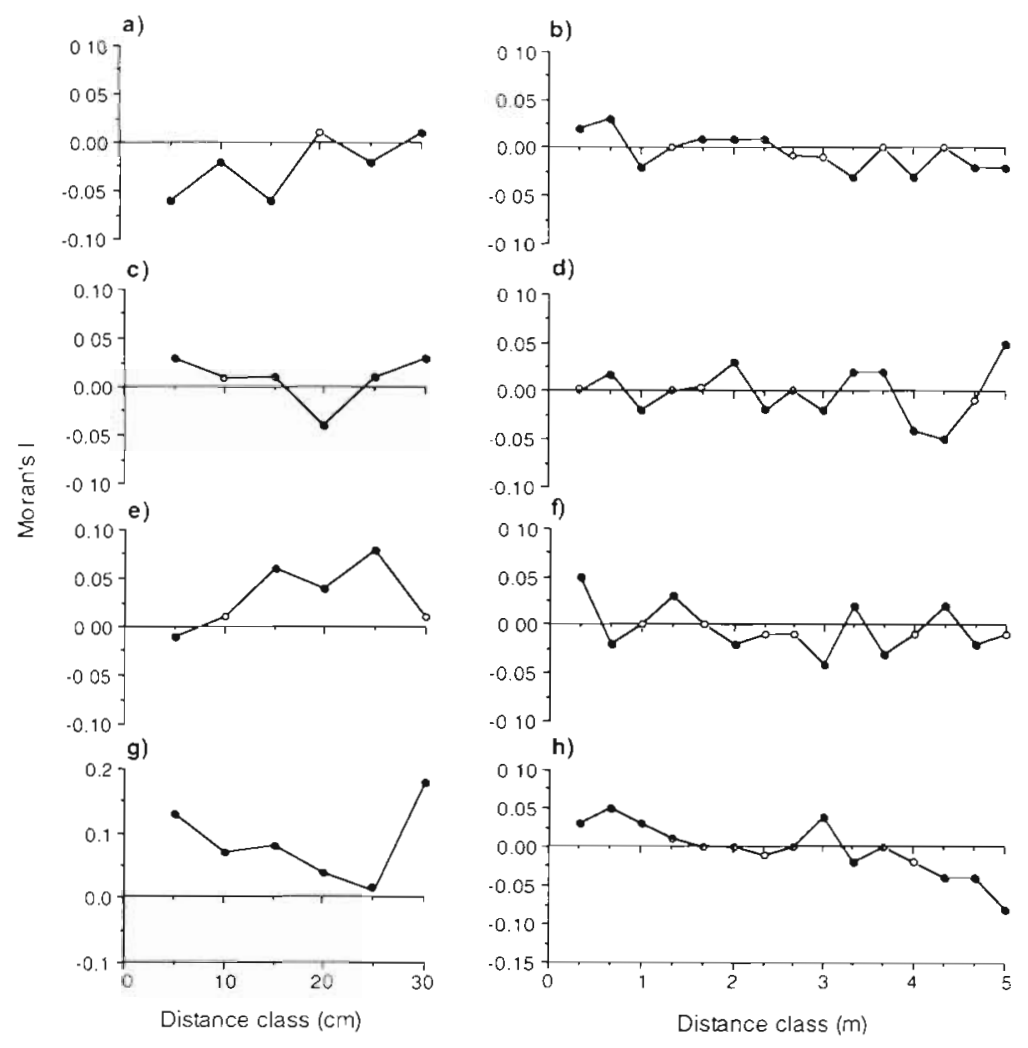

d)
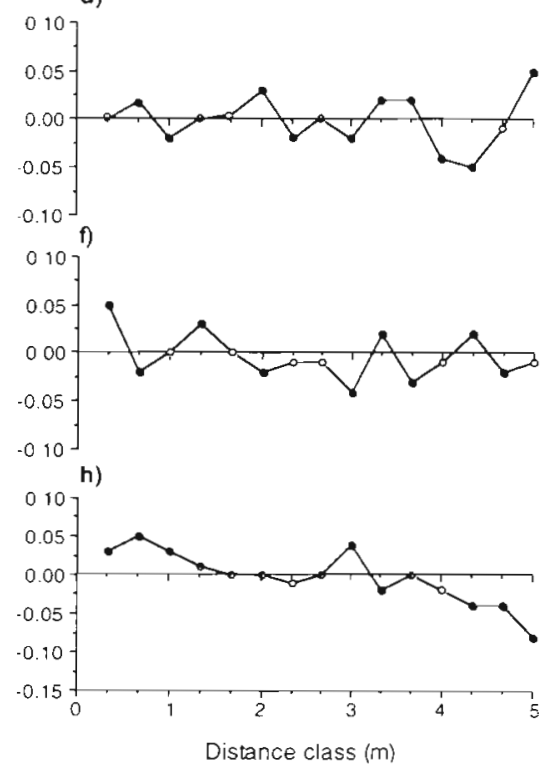

Fig. 3. Moran's I correlograms for Macomona liliana $(a, b)$ juveniles and $(c, d)$ adults and Austrovenus stutchburyi $(e, f)$ juveniles and $(g, h)$ adults at the muddy site. Correlograms on the left and right of the figure were obtained using data from the small and large cores respectively. ( Values of Moran's I significant at the $5 \%$ probability level
Fig. 4. Austrovenus stutchburyi. Correlograms for juvenile bivalves at the mlluciuy site using iags of (d) $33 \mathrm{~cm}$. (b, c) $67 \mathrm{~cm}$ and $(\mathrm{d}$, e) $1 \mathrm{~m}$. ( ) Values of Moran's I or Geary's c significant at the $5 \%$ probability level
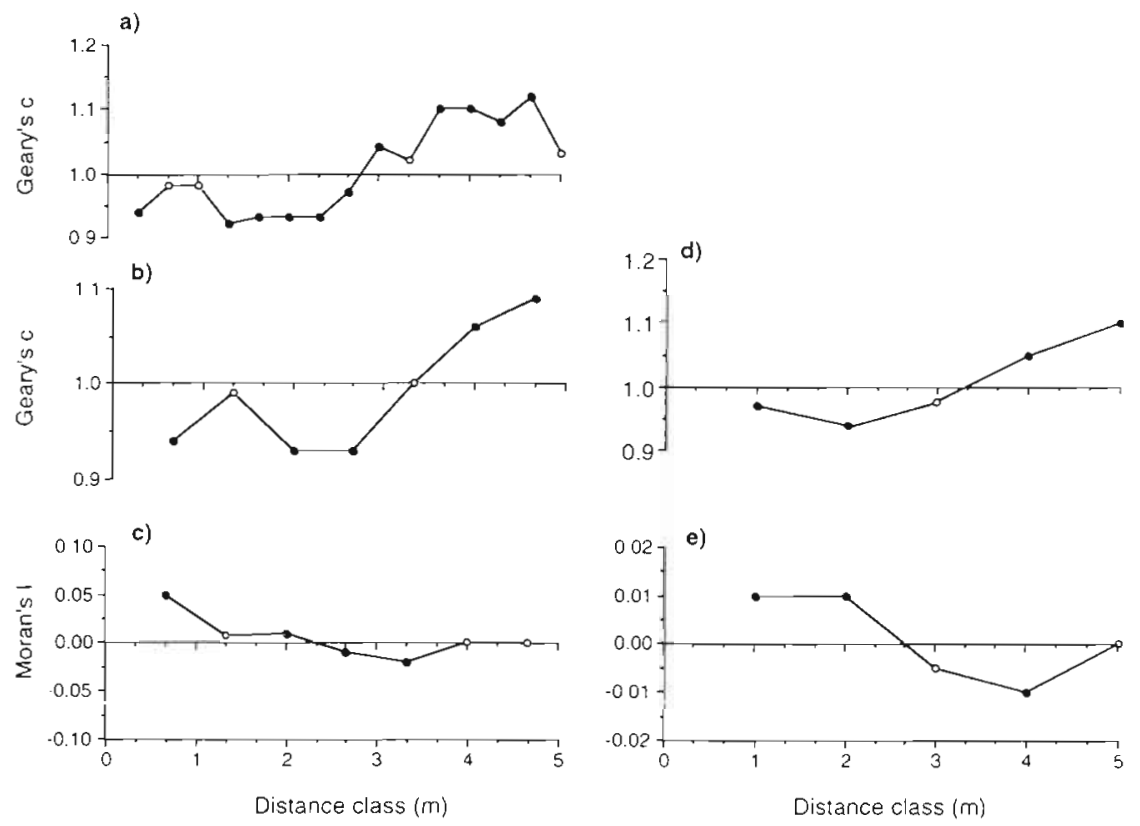
Table 6. Pearson's correlatıon coefficients (adjusted for spatial autocorrelation) found using data from both sites for (a) Macomona liliana juveniles and (b) Austrovenus stutchburyi juveniles with adults of the 2 species when the grain is changed. Significance level was adjusted by Bonferroni's method for the number of analyses run. ns:not sifnuficant

\begin{tabular}{|cccc|}
\hline $\begin{array}{c}\text { Grain } \\
(\mathrm{cm})\end{array}$ & $\mathrm{df}$ & $\begin{array}{c}\text { M. liliana } \\
\text { adults }\end{array}$ & $\begin{array}{c}\text { A. stutchburyi } \\
\text { adults }\end{array}$ \\
\hline (a) $\begin{array}{ccc}\text { M. liliana juveniles } \\
5\end{array}$ & 539 & 0.19 & $\mathrm{~ns}$ \\
10 & 107 & 0.47 & $\mathrm{~ns}$ \\
1.5 & 35 & 0.68 & $\mathrm{~ns}$ \\
20 & 17 & 0.69 & 0.35 \\
25 & 17 & 0.77 & ns \\
(b) A. stutchburyi juveniles & & \\
5 & 539 & 0.21 & $\mathrm{~ns}$ \\
10 & 107 & 0.54 & $\mathrm{~ns}$ \\
15 & 35 & 0.70 & $\mathrm{~ns}$ \\
20 & 17 & 0.75 & $\mathrm{~ns}$ \\
25 & 17 & 0.82 & ns \\
\hline
\end{tabular}

Table 7 Macomona liliana and Austrovenus stutchburyi. Morisita's index of dispersal found at (a) the sandy site and (b) the muddy site when the grain is changed. Values from -0.5 to +0.5 are considered to indicate random distributions. Values $>0.5$ and $<-0.5$ indicate aggregated and uniform distributions respectively

\begin{tabular}{|c|c|c|c|c|c|}
\hline & $5 \mathrm{~cm}$ & $10 \mathrm{~cm}$ & $15 \mathrm{~cm}$ & $20 \mathrm{~cm}$ & $25 \mathrm{~cm}$ \\
\hline \multicolumn{6}{|c|}{ (a) Sandy site } \\
\hline \multicolumn{6}{|c|}{ A. stutch buryi } \\
\hline Juvenile & 0.56 & -0.53 & 0.01 & 0.05 & 0.17 \\
\hline Adult & 0.56 & 0.52 & 0.52 & 0.53 & 0.53 \\
\hline \multicolumn{6}{|l|}{ M. liliana } \\
\hline Juvenile & 0.60 & 0.19 & 0.52 & 0.53 & 0.47 \\
\hline Adult & -0.42 & -0.55 & -0.42 & -0.12 & -0.17 \\
\hline \multicolumn{6}{|c|}{ (b) Muddy site } \\
\hline \multicolumn{6}{|c|}{ A. stutchburyi } \\
\hline Juvenile & 0.49 & 0.21 & 0.52 & 0.53 & 0.54 \\
\hline Aduit & 0.51 & 0.51 & 0.51 & 0.53 & 0.53 \\
\hline \multicolumn{6}{|l|}{ M. Liliana } \\
\hline Juvenile & 0.48 & 0.07 & -0.33 & -0.25 & 0.54 \\
\hline Adult & -0.20 & -0.56 & -0.38 & 0 & -0.19 \\
\hline
\end{tabular}

\section{DISCUSSION}

As predicted, most of the spatial patterns found in this study were the same in intensity and patch size at both sites (Prediction 1). Given the level of differences we were interested in, i.e. small $(<33 \mathrm{~cm})$, versus medium ( $50 \mathrm{~cm}$ to $1 \mathrm{~m}$ ) versus large scale $(\geq 2 \mathrm{~m})$ and the number of samples collected at the 2 sites, we are confident about the similarities in spatial structure, even though techniques to calculate power to detect differences between correlograms are not available.
Finding similar distribution patterns for Macomona liliana and Austrovenus stutchburyi in the 2 different habitat types gives us confidence that those spatial patterns are a result of species biology rather than purely a reflection of local environmental conditions, e.g. differences in hydrological conditions and sediment grain size. Furthermore, it allows us to ascribe the majority of the spatial patterns to biotic processes common to both sites, i.e. active movement and individual interactions

At the start of this study we predicted patch structure, based on our knowledge of the life history of the 2 species. The results refute few of these predictions. The relatively sedentary Macomona liliana adults displayed patchiness on small and medium scales but not on the large scale (Prediction 2). The more mobile Austrovenus stutchburyi adults and juveniles did display patchiness on the large scale (Prediction 3). We found small-scale patterns in the spatial distribution of juvenile $M$. liliana (Prediction 4) even though individuals of this size are highly mobile. Recent theoretical studies indicate that local populations of highly mobile organisims may display dynamics that are less sensitive to the spatial configuration of local habitat patches than more sedentary species (Kotliar \& Wiens 1990, Milne 1991a). Our study does not support this theory for organisms such as juvenile $M$. liliana that are not continuously mobile and exhibit habitat choice and/or differential survival.

Much of the recent ecological literature emphasises the importance of incorporating scale into studies (e.g. Dayton \& Tegner 1984, Powell 1989, Wiens 1989, Levin 1992). Recognising that the effect of processes may differ depending on scale has important implications for developing a more integrated set of ecological theories. In the search for consistent patterns across scale, it has been suggested that, for terrestrial systems, allometric relationships (Brown 1981, Peters 1983, Swihart et al. 1988) may be used to predict scaling functions for organisms of different sizes. That is, is there a positive relationship between the size of an organism and the size of patches it responds to or forms (Prediction 5)? We found smaller-scale (i.e. $25 \mathrm{~cm}$ diameter) patches in juvenile Austrovenus stutchburyi abundance, approximately one-fifth the size of the smallest patches (i.e. 1.0 to $1.3 \mathrm{~m}$ diameter) detected for the adults at both sites.

A priori predictions about the intensity of the spatial patterns based on feeding mode were supported by data for the adults of both species only. Adults of the deposit feeder Macomona liliana displayed a uniform distribution at the $10 \mathrm{~cm}$ scale at both sites (Prediction 6) and adults of the suspension feeder Austrovenus stutchburyi displayed an aggregated distribution at all scales at both sites (Prediction 7). Juveniles of the 2 species, however, did not display any consis- 
tent patterns at the 2 sites. However, feeding mode can be affected by environmental factors and age. For example, tellinid species have been shown to switch from deposit feeding to suspension feeding in response to different environmental pressures (Bubnova 1972, 'Olafsson 1986). In particular, previous laboratory studies in aquaria have suggested that juvenile $M$. liliana are not strict deposit feeders (Pridmore et al. 1991).

A significant correlation between adult and juvenile Macomona liliana was found (Prediction 8) only when all the data from both sites was utilized; therefore, habitat differences could not be explored. The correlation found was positive and adult and juvenile $M$. liliana exhibited similarly sized spatial distributions at the medium-scale $(67 \mathrm{~cm}$ to $1 \mathrm{~m}$ diameter). We found no significant correlations between adult Austrovenus stutchburyi and juveniles of either species or between adults of the 2 species.

Descriptions of spatial distributions of groups of individuals can be utilized to provide theories about movement, responses and interactions within and between adjacent groups that can be tested in further studies. For example, the consistency in size of the larger patches exhibited by adults of the 2 species at both sites suggests that these patches are of such a size that an individual rarely moves out of a patch. For adult Macomona liliana, we suggest an individual neighbourhood is at least $5 \mathrm{~cm}$ radius (from the grain at which the intensity of pattern changed from uniform to random) and that the upper limit of normal net movement is less than $1 \mathrm{~m}$. The size of this upper limit matches that suggested for a 5 mo period by Thrush et al. (1994). We also found smaller patches of around $15 \mathrm{~cm}$ diameter in the abundance of adult $M$. liliana; these are consistent with the maximum movement rates of $10 \mathrm{~cm}$ over 2 tides previously observed (authors' unpubl. data).

The role of correlative studies such as this is to help in the design of future hypothesis testing studies and to link studies conducted at different scales. For example, dispersive or spatial models could be used to determine whether patches are stable with respect to expected scale of movements. Similarly, manipulative experiments on these 2 species could be designed to take advantage of the patch sizes predicted by this study. However, using correlative studies with a priori predictions does allow the ecologist to discard models that do not elicit the predicted response. In this study we have found evidence that highly mobile organisms are sensitive to local patch dynamics. Most importantly though, over the scales we investigated, individual mobility and interactions appear to be important processes influencing the observed spatial patterns of both juveniles and adults of 2 species from different functional groups in 2 different habitat types. We made no a priori predictions concerning the influence of other macrofaunal species on the spatial patterns of Macomona liliana and Austrovenus stutchburyi. In previous studies conducted near these sites, the only strong species interactions noted on this scale involved M. liliana (Thrush et al. 1992, 1994). In fact, the most common macrofaunal species at both sites, Aonides oxycephala, had previously been demonstrated to have little influence on other species' abundances (Thrush et al. 1992). However, testing similar predictions for a larger variety of species and habitats is needed to identify the general importance of size, mobility and feeding mode in determining distribution patterns.

Explicit descriptions of patterns of community or population heterogeneity can provide a stepping stone to inferring relevant processes. We found spatial patterns were more consistent between sites than they were between organisms of differing mobility, feeding mode and body size. However, patchiness was always exhibited on more than 1 scale. Thus, understanding the scale over which processes and responses operate may be necessary both in order to link spatial patterns to the processes which structure them and in developing cause and effect studies which are sensitive to responses which change with scale. The differently sized patches we found appeared to be the result both of different processes being important at different scales and of processes acting over different temporal scales. For example, the smallest size of patchiness exhibited by adult Macomona liliana is most likely defined by feeding characteristics and movements over short time scales, while the larger patches may be a reflection of movements over a longer time scale. Although it is possible that the larger patches may be a reflection of patchy settlement, it seems unlikely, given the different hydrodynamic conditions, that this would result in similarly sized patches at both sites.

Processes operating at the level of individuals, expressed in a dynamic, spatially patterned environment, help generate larger-scale ecological patterns, e.g. inter-individual interactions enhancing or decreasing survivability, and sensitivity of mobile postsettlers to small-scale local patch dynamics. Even within essentially fluid environments (e.g. oceans, lakes and atmosphere) individual mobility and interactions may be expected to be important (Barry \& Dayton 1991, Schneider 1991). Indeed, these types of processes probably play a fundamental role in maintaining such large patches. Certainly, our study suggests that, even with larqe variations in habitat characteristics, small-scale processes can produce similar spatial patterns. Utilizing theories of choice, movement and hydrodynamics on several scales may allow 
marine ecologists to link individual use of space, mobility and interactions to population and community level phenomena. Combining this with attempts to predict the relative importance of different processes through an understanding of an organism's natural history would allow a much better appreciation of the effects generalising from the results of small-scale studies. In other words, knowledge of natural history can provide a route to generalisations at higher levels of organisation.

Acknowledgements. We thank Karl Mischewski for his help in sampling, Delwyn Hudson and Susan Hassler for their assistance in sorting samples, and Richard Ford for helping with identifications and sizing bivalves. Paul Dayton and John Wiens helpfully commented on an earlier draft of the manuscript.

\section{LITERATURE CITED}

Addicot JF, Aho JM. Antolin MF, Padilla DK, Richardson JS, Soluk DA (1987) Ecological neighborhoods: scaling environmental patterns. Oikos 49:340-346

Barry JP, Dayton PK (1991) Physical heterogeneity and the organisation of marine communities. In: Kolasa J, Pickett STA (eds) Ecological heterogeneity. Springer-Verlag, New York, p 270-321

Brown JH (1981) Two decades of homage to Santa Rosalia: towards a general theory of diversity. Am Zool 21:877-888

Bubnova NP (1972) The nutrition of the detritus-feeding molluscs, Macoma balthica (L.) and Portlandia artica (Gray), and their influence on bottom sediments. Oceanologia 12. 899-905

Caswell H, Cohen JE (1991) Communities in patchy environments: a model of disturbance, competition, and heterogeneity. In: Kolasa J, Pickett STA (eds) Ecological heterogeneity. Springer-Verlag, New York, p 97-122

Cliff A, Ord J (1981) Spatial processes: models and applications. Pion Press, London

Commito JA, Thrush SF, Pridmore RD. Hewitt JE, Cummings VJ (1995) Dispersal dynamics in a wind-driven benthic system. Limnol Oceanogr 40:1513-1518

Connell JH (1963) Spatial patterns of several marine benthic invertebrates. Res Pop Ecol 5:87-101.

Cummings VJ, Pridmore RD, Thrush SF, Hewitt JE (1993) Emergence and floating behaviours of post-settlement juveniles of Macomona liliana (Bivalvia: Tellinacea). Mar Behav Physiol 24:25-32

Cummings VJ, Pridmore RD. Thrush SF, Hewitt JE (1995) Post-settlement movement by intertıdal benthic macrofauna: do common New Zealand species drift in the water column? NZ J Mar Freshwat Res 29:59-67

Cummings VJ, Pridmore RD, Thrush SF, Hewitt JE (In press) The effect of the spionid polychaete Boccardia syrtis on the distribution and survival of juvenile Macomona liliana (Bivalvia: Tellinacea). Mar Biol

Dayton. PK, Tegner MJ (1984) The importance of scale in community ecology: a kelp forest example with terrestrial analogs. In: Price PW. Slobodchikoff CN, Gaud WS (eds) A new ecology: novel approaches to interactive systems. J Wiley \& Sons, New York, p 457-483

Gage JD, Geekie AD (1973) Community structure of the benthos in Scottish sea-lochs. II. Spatial pattern. Mar Biol 19: $41-53$
Griffith DA (1987) Spatial autocorrelation: a primer. Association of American Geographers, Washington, DC

Holme NA (1950) Population dispersion in Tellina tenuis da Costa. J Mar Biol Ass UK 29:267-280

Isaaks EH, Srivastava RM (1989) Applied geostatistics. Oxford University Press, Oxford

Jumars PA, Thistle D, Jones M (1977) Detecting two-dimentional spatial structure in biological data. Oecologia 28 : $109-123$

Krebs CJ (1989) Ecological methodology. Harper \& Row, New York

Kotliar NB, Wiens JA (1990) Multiple scales of patchiness and patch structure: a hierarchical framework for the study of heterogeneity. Oikos 59:253-260

Legendre L, Legendre P (1983) Numerical ecology. Elsevier Scjentific, Amsterdam

Legendre P, Fortin MJ (1989) Spatial pattern and ecological analysis. Vegetatio 80:107-138

Levin LA (1981) Dispersion, feeding behaviour and competition in two spionid polychaetes. J Mar Res 39:99-117

Levin SA (1992) The problem of pattern and scale in ecology. Ecology 73:1943-1967

Levinton JS (1972) Spatial distribution of Nucula proxima Say (Protobranchia): an experimental approach. Biol Bull 143: $175-183$

Livingston RJ (1987) Field sampling in estuaries: the relationship of scale to variability. Estuaries 10:194-207

Maurer BA (1985) Avian community dynamics in desert grassland: observational scale and hierarchical structure. Ecol Monogr 55:295-312

Milne BT (1991a) Heterogeneity as a multiscale characteristic of landscapes. In: Kolasa, J, Pickett STA (eds) Ecological heterogeneity. Springer-Verlag, New York, p 69-84

Milne BT (1991b) Lessons from applying fractal models to landscape patterns. In: Turner MG, Garner RH (eds) Quantative methods in landscape ecology. Springer-Verlag. New York, p 198-235

Milne BT (1992) Spatial aggregation and neutral models in fractal landscapes. Am Nat 139:32-54

Oden NL (1984) Assessing the significance of a spatial correlogram. Geogr Anal 16:1-15

'Olafsson EB (1986) Density dependence in suspension feeding and deposit feeding populations of the bivalve, Macoma balthica: a field experiment. J Anim Ecol 55: $517-526$

O'Neill RV, Gardner RH, Milne BT, Turner MG, Jackson B (1991) Heterogeneity and spatial hierarchies. In: Kolasa J, Pickett STA (eds) Ecological heterogeneity. SpringerVerlag, New York, p 85-96

Peters RH (1983) The ecological implications of body size Cambridge University Press, New York

Pielou C (1977) Mathematical ecology. J Wiley \& Sons, New York

Powell AWB (1979) New Zealand mollusca: marine, land and freshwater shells. Collins, Wellington

Powell TM (1989) Physical and biological scales of variability in lakes, estuaries and the coastal ocean. In: Roughgarden J, May RM, Levin SA (eds) Perspectives in ecological theory. Princeton University Press, Princeton, p 1.57-176

Pridmore RD, Thrush SF, Wilcock RJ, Smith. TJ, Hewitt JE, Cummings VJ (1991) Effect of the organochlorine pesticide technical chlordane on the population structure of suspension and deposit feeding bivalves. Mar Ecol Prog Ser 76:261-271

Reise K (1979) Spatial configurations generated by motile benthic polychaetes. Helgoländer Meeresunters 32 : $55-72$ 
Root $T$ (1988) Energy constraints on avian distributions and abundances. Ecology 69:330-339

Schneider DC (1991) The role of fluid dynamics in the ecology of marine birds. Oceanogr Mar Biol A Rev 29:487-521

Schneider DC. Piatt J F. (1986) Scale-dependent correlation of seabirds with schooling fish in a coastal ecosystem. Mar Ecol Prog Ser 32:237-246

Sokal RR (1979) Ecological parameters inferred from spatial correlograms. In: Patil GP, Rosenweig M (eds) Contempory quantitatıve ecology and related ecometrics. International Co-operative Publishing House, Fairland, MD. p $167-196$

Sokal RR, Oden NL (1978) Spatial autocorrelation in biology, 2. Some biological implications and four applications of evolutionary and ecological interest. Biol J Linn Soc 10:229-249

Steele JH (1985) Spatial patterns in planktonic communities. Plenum Press, New York

Swihart RK, Slade NA, Bergstrom BJ (1988) Relating body size to rate of home range use in mammals. Ecology 69: 393-399

Thrush SF, Hewitt JE, Pridmore RD (1989) Patterns in the spatial arrangement of polychaetes and bivalves in intertidal sandflats. Mar Biol 102:529-536

Thrush SF, Pridmore RD. Hewitt JE, Cummings VJ (1991) Impact of ray feeding disturbances on sandflat macroben-

This article was presented by J. Gray (Senior Editorial Advisorl, Oslo, Norway thos: do communities dominated by polychaetes or shellfish respond differently? Mar Ecol Prog Ser 69:245-252

Thrush SF, Pridmore RD, Hewitt JE, Cummings VJ (1992) Adult infauna as facilitators of colonization on intertidal sandflats. J Exp Mar Biol Ecol 159:253-265

Thrush SF, Pridmore RD, Hewitt. JE, Cummings VJ (1994) The importance of predators on a sandflat: interplay between seasonal changes in prey densities and predator effects. Mar Ecol Prog Ser 107:211-222

Wartenberg D (1989) SAAP-A spatial autocorrelation analysis programme, version 4.3. Department of Environmental \& Community Medicine, Robert Wood Johnson Medical School, University of Medicine \& Dentistry of New Jersey, Piscataway

Whitaker RH, Levin SA (1977) The role of mosalic phenomena in natural communities. Theor Popul Biol 12:117-139

Wiens J A. (1986) Spatial scale and temporal variation in studies of shrubsteppe birds. In: Diamond J, Case TJ (eds) Community ecology. Harper \& Row, New York, p 154-171

Wiens J A. (1989) Spatial scale in ecology. Funct Ecol 3: 385-397

Williamson MH, Lawton JH (1991) Fractal geometry of ecological habitats. In: Bell SS, McLoy ER, Muschinsky HR (eds) Habitat structure: the physical arrangement of objects in space. Chapman \& Hall, London, p 69-86

Manuscript first received: August 17, 1995

Revised version accepted: December 12, 1995 